\title{
Perlindungan Hukum Terhadap Hak-Hak Masyarakat Adat Di Kabupaten Pelalawan Terkait Dengan Penerbitan Ijin Lahan
}

\author{
Maryati Bachtiar, Riska Fitriani
}

DATA NASKAH

Masuk: 21 November 2016

Diterima: 4 April 2017

Terbit: 1 Juni 2017

KORESPONDEN PENULIS:

Fakultas Hukum Universitas Riau Jl. Pattimura No. 9 Gobah, Pekanbaru 28132. Email:

bloomengirl78@gmail.com

\section{ABSTRACT}

Overlap the land permit granted by the Government of Pelalawan result of indigenous people communal land taken without regard to the rights of the local population. In issuing licenses, many customary rights of indigenous peoples are disadvantaged. Because in practice the country has not fully provide legal protection of the rights of indigenous peoples, as in the case of customary land disputes and conflicts/communal, indigenous peoples still in a weak position associated with the policies issued by the state. Need for Local Regulation in Pelalawan governing the legal protection of the rights of indigenous peoples, so that indigenous land disputes and conflicts/customary in Pelalawan can be minimized.

Keywords: Rights, Indigenous Peoples, Pelalawan, Permit

\section{ABSTRAK}

Tumpang tindih ijin lahan yang diberikan oleh pemerintah Kabupaten Pelalawan mengakibatkan tanah ulayat milik masyarakat adat diambil tanpa memperhatikan hak-hak penduduk setempat. Dalam penerbitan ijin, banyak hak ulayat masyarakat adat yang dirugikan. Karena dalam pelaksanaannya negara belum sepenuhnya memberikan perlindungan hukum terhadap hak-hak masyarakat adat, karena dalam kasus sengketa dan konflik tanah adat/ulayat, masyarakat adat masih berada dalam posisi lemah terkait dengan kebijakan yang dikeluarkan oleh negara. Perlu adanya Perda di Kabupaten Pelalawan yang mengatur perlindungan hukum terhadap hak-hak masyarakat adat, sehingga sengketa dan konflik tanah adat/ulayat di Kabupaten Pelalawan dapat diminimalisir.

Kata kunci: Hak, Masyarakat Adat, Kabupaten Pelalawan, Ijin

\section{PENDAHULUAN}

Berbicara mengenai hak atas tanah, terdapat berbagai hak yang dapat 


\section{MEDIA
HUKUM}

dimiliki oleh masyarakat, maupun negara seperti hak milik, hak guna usaha, hak guna bangunan, hak pakai, hak sewa, hak membuka tanah, hak memungut hasil hutan, hak guna air, hak pemeliharaan dan penangkapan ikan, hak guna ruang angkasa, serta beberapa hak lainnya yang diatur melalui undang-undang ini. Dengan adanya hak-hak atas tanah tersebut keberlanjutan hidup manusia akan semakin mudah, sebab tanpa adanya tanah dan hak-haknya sangat tidak mungkin adanya keberlanjutan hidup manusia (Sunarno, 2015:2). Adapun dalam Undang-undang No.5 Tahun 1960 (UUPA), Pasal 2 ayat (1) menyebutkan bahwa bumi, air dan ruang angkasa termasuk kekayaan yang terkandung di dalamnya pada tingkat yang tertinggi dikuasai oleh negara sebagai organisasi kekuasaan seluruh rakyat. Namun, dalam praktek masih banyak sekali ditemui masalah kepemilikan tanah yang tidak jarang berkembang menjadi kerusuhan dan konflik kekerasan baik antara sesama warga masyarakat maupun antara masyarakat dengan aparat pemerintah. Lebih jauh, keadaan ini berakibat negatif bagi iklim investasi yang diharapkan dapat menunjang perekonomian bangsa yang terpuruk, salah satunya di Kabupaten Pelalawan.

Kabupaten Pelalawan merupakan pemekaran dari Kabupaten Kampar, yang dibentuk berdasarkan Undangundang No. 53 Tahun 1999. Pada awalnya terdiri atas 4 (empat) wilayah kecamatan, yakni: Langgam, Pangkalan Kuras, Bunut, dan Kuala Kampar. Kemudian setelah terbit Surat Dirjen PUOD No.138/1775/PUOD tanggal 21 Juni 1999 tentang pembentukan 9 (sembilan) Kecamatan Pembantu di Provinsi Riau, maka Kabupaten Pelalawan dimekarkan menjadi 9 (sembilan) kecamatan, yang terdiri atas 4 (empat) kecamatan induk dan 5 (lima) kecamatan pembantu, tetapi berdasarkan SK Gubernur Provinsi Riau No. 136/TP/1443, Kabupaten Pelalawan dimekarkan kembali menjadi 10 (sepuluh) kecamatan. Namun, setelah terbitnya Peraturan Daerah Kabupaten Pelalawan No.06 Tahun 2005, maka Kabupaten Pelalawan terdiri atas 12 (dua belas) kecamatan.

Permasalahan sengketa tanah yang berujung konflik banyak terjadi di Kabupaten Pelalawan. Terlebih hal ini tidak hanya melibatkan tanah milik perseorangan atau badan hukum tetapi juga melibatkan tanah milik masyarakat adat yang jelas dilindungi haknya untuk menempati dan mengelola tanah yang mereka tempati sebagai tanah ulayat. Pemerintah telah memberikan ijin pemanfaatan lahan di Kabupaten Pelalawan seluas 866.261 Ha dari 1.392.494 Ha luas kabupaten. Ijin yang diberikan tersebut terdiri dari 387.668 Ha izin perkebunan dan 478.593 Ha izin HTI (Yayasan Hutan Riau, 2015). Namun ironisnya dari penerbitan ijin tersebut, banyak hak ulayat masyarakat adat di Kabupaten Pelalawan yang dirugikan. Hal ini dapat dilihat dari tumpang tindihnya ijin lahan yang diberikan oleh pemerintah sehingga mengakibatkan tanah ulayat milik masyarakat adat di Kabupaten Pelalawan diambil tanpa memperhatikan hakhak mereka.

\section{METODE PENELITIAN}

\section{Jenis Penelitian}

Jenis penelitian yang dilakukan ini merupakan jenis penelitian empiris (yuridis sosiologis). Penelitian Hukum Sosiologis atau Empiris adalah metode penelitian yang dilakukan untuk mendapatkan data primer (Soerjono Soekanto, 1986). Penelitian ini bertujuan untuk memperoleh data yang lengkap, tepat dan dapat dipertanggungjawabkan kebenarannya. Pendekatan yuridis dilakukan dengan mengkaji, mempelajari dan menelaah teori-teori, konsepkonsep, doktrin-doktrin hukum serta peraturan perundangundangan, dan juga berbagai data-data yang didapatkan dari situs-situs internet yang berkaitan dengan permasalahan Perlindungan Hukum Terhadap Hak-Hak Masyarakat Adat Di Kabupaten Pelalawan Terkait Dengan Penerbitan ljin Lahan. Penelitian ini bersifat deskriptif dan cenderung menggunakan analisis. Proses dan makna (perspektif subjek) lebih ditonjolkan dalam penelitian kualitatif. Landasan teori dimanfaatkan sebagai pemandu agar fokus penelitian sesuai dengan fakta di lapangan. Selain itu, landasan teori juga bermanfaat untuk memberikan gambaran umum tentang latar penelitian dan sebagai bahan pembahasan hasil penelitian.

\section{Lokasi Penelitian}

Penelitian ini dilakukan di Kabupaten Pelalawan, karena banyak terjadi sengketa tanah masyarakat hukum adat terkait dengan penerbitan ijin lahan yang merugikan hak-hak masyarakat hukum adat di Kabupaten Pelalawan. 


\section{Responden}

Adapun yang akan menjadi responden dalam penelitian ini adalah:

1. Tokoh Masyarakat di Kabupaten Pelalawan;

2. Ketua Adat Masyarakat Hukum Adat di Kabupaten Pelalawan;

3. Badan Pertanahan Kabupaten Pelalawan;

4. DPRD Kabupaten Pelalawan.

\section{Sumber Data}

Data yang akan digunakan dalam penelitian ini adalah:

a. Data primer adalah data yang diperoleh secara langsung dari responden dengan menggunakan alat pengumpulan data berupa wawancara.

b. Data sekunder adalah data yang diperoleh dari peraturan perundang-undangan dan literatur yang berhubungan dengan penelitian ini.

c. Data tersier adalah data yang diperoleh melalui kamus yang berfungsi untuk mendukung data primer dan sekunder.

\section{Teknik Pengumpulan Data}

a Observasi

Yaitu Pengumpulan data yang dibutuhkan dalam penelitian ini dengan cara pengamatan langsung terhadap objek penelitian yaitu Perlindungan Hukum Terhadap HakHak Masyarakat Adat Di Kabupaten Pelalawan Terkait Dengan Penerbitan ljin Lahan.

b. Wawancara

Yaitu mengadakan proses tanya jawab langsung kepada responden dengan pertanyaan-pertanyaan terstruktur terkait permasalahan.

c. Kajian Kepustakaan

Untuk memperlengkap data yang dibutuhkan dalam penelitian, peneliti melakukan pengumpulan data dengan literatur kepustakaan yang mempunyai hubungan logis dengan permasalahan yang sedang diteliti, dilakukan guna mencari data sekunder sebagai pendukung data primer.

\section{Analisis Data}

Data yang telah dikumpulkan akan dianalisis secara deskriptif kualitatif, peneliti dalam menganalisis berkeinginan untuk memberikan gambaran atau pemaparan atas objek penelitian (Mukti Fajar dan Yulianto Achmad, 2010:183)، dengan menggunakan uraian kalimat untuk menjelaskan hubungan antara teori yang ada dengan kenyataan yang ada di lapangan melalui tahap-tahap sebagai berikut:

a. Tahap Persiapan

Peneliti mempersiapkan data-data yang diperlukan untuk melakukan observasi ke lokasi penelitian, mempersiapkan surat izin penelitian, dan mempersiapkan daftar pertanyaan wawancara untuk responden.

b. Tahap Pelaksanaan

Peneliti melakukan penelitian dengan cara mewawancara semua responden yang menjadi objek penelitian.

c. Tahap Penyelesaian

Pada tahap ini dilakukan berbagai kegiatan yaitu menganalisis data hasil kegiatan penelitian ini dengan mengelompokkan serta menghubungkan aspek-aspek yang berkaitan, kemudian dilanjutkan dengan penulisan laporan awal serta konsultasi. Setelah itu dilakukan penyempurnaan laporan akhir.

\section{HASIL PENELITIAN DAN ANALISIS}

1. Faktor-Faktor Penyebab Tumpang Tindih Penggunaan Lahan di Kabupaten Pelalawan

Pemicu permasalahan konflik lahan antara masyarakat adat dengan perusahaan sebenarnya adalah sebuah permasalahan yang sederhana, dimana pada zaman dahulu perusahaan membuka lahan berdasarkan ijin yang dikeluarkan pemerintah. Perusahaan pada awalnya sudah melakukan pendekatan dengan pihak desa, tokoh masyarakat, tokoh adat bahkan sudah ada bukti ganti rugi. Namun, sekarang muncul protes anak kemenakan, yang tidak bisa menerima hal tersebut. Permasalahan ini memang sulit, susah juga menilai pihak mana yang salah, karena semua pemangku kepentingan juga sama saja, sehingga ada peluang kesalahan berasal dari masing-masing pihak.

Selain itu, seperti Taman Nasional Tesso Nilo (TNTN) yang luasnya \pm 80 ribu ha, diresmikan sekitar tahun 2004. Pelepasan tahap I (pertama) seluas \pm 30 ribu ha, dan pelepasan tahap II (kedua) seluas \pm 40 ribu ha. Di dalam TNTN itu juga terdapat tanah ulayat, juga terdapat desa/ kampung. Kampung/ desa tersebut sudah ada sebelum status TNTN itu ada, tetapi ada juga masyarakat yang mengolah 


\section{MEDIA
HUKUM}

tanah setelah status TNTN itu diresmikan. Pihak pengelola pada waktu itu juga tidak memberi batas yang jelas terhadap batas TNTN. Ketika terjadi permasalahan seperti ini terjadi maka akan sulit untuk menentukan siapa yang harus disalahkan. Menurut Bapak AH Makmur (wawancara, 2015), memang harus ada regulasi yang jelas mengenai tanah adat ini, sehingga pihak-pihak berkepentingan tidak merasa dirugikan dengan realita yang ada di lapangan.

Di beberapa kecamatan yang ada di Kabupaten Pelalawan itu terdapat desa/ kampung yang wilayah mereka berada dalam kawasan izin perusahaan, padahal mereka sudah ada semenjak negara ini belum merdeka, bahkan sebelum perusahaan tersebut mendapat izin. Namun, pemerintah tetap saja mengeluarkan izin. Mengenai hal ini, Bapak A.H. Makmur (wawancara, 2015) tidak mengetahui secara persis dahulunya seperti apa proses pengeluaran izin tersebut. Bisa saja zaman itu main foto dari udara, tanpa melihat di bawah itu ada desa/ kampung. Apalagi zaman dahulu masih banyak pohon, sehingga kampung/ desa tersebut tampak dari udara hijau saja. Terkadang ini menjadi celah hukum juga, sebagai contoh ada sebuah kawasan hutan, terhadap kawasan tersebut perusahaan bisa mengajukan pelepasan kawasan hutan sementara masyarakat kecil tidak, sehingga ini juga menimbulkan ketidakadilan.

Konflik pertanahan ini menjadi konflik yang sangat rumit, penyelesaiannya sangat panjang, butuh waktu, biaya dan tenaga yang tidak sedikit. Apalagi tanah ini mempunyai nilai batiniah bagi masyarakat adat. Sejauh ini belum ada pengaturan mengenai tanah adat di Kabupaten Pelalawan, yang ada hanya Peraturan Daerah Provinsi Riau Nomor 10 Tahun 1994 Tentang RTRW dan Peraturan Daerah Kabupaten Pelalawan Nomor 23 Tahun 2011 Tentang Tata Ruang Kabupaten Pelalawan. Hal inilah yang mempersulit masyarakat adat yang ingin memperjuangkan hak-haknya. Selama ini konflik antara masyarakat adat dengan perusahaan menyangkut lahan/ tanah yang diklaim masyarakat sebagai tanah ulayat pasti ada, karena menurut menurut lembaga adat/ masyarakat tanah yang telah ditempatinya sejak nenek moyang dahulu adalah tanah milik masyarakat adat tersebut, tetapi menurut perusahaan, tanah tersebut juga merupakan milik perusahaan berdasarkan ijin yang diberikan pemerintah. Pihak kepolisian Pangkalan Kuras sering mengamankan demonstrasi yang dilakukan masyarakat terhadap perusahaan.

Rekapitulasi mengenai jumlah konflik yang terjadi antara masyarakat dengan perusahaan menyangkut klaim tanah ulayat/ tanah adat selama satu tahun bisa mencapai 10 sampai 20 kasus, dan mengenai konflik tanah ulayat/ adat ini kasusnya meningkat setiap tahun. Hal ini dikarenakan faktor ekonomi masyarakat, masyarakat juga semakin susah mencari lahan untuk bercocok tanam, ditambah lagi kesenjangan sosial yang semakin tinggi antara masyarakat dengan perusahaan. Kepolisian Sektor Pangkalan Kuras sendiri dalam menyikapi konflik yang terjadi antara masyarakat dengan perusahaan tidak bisa berbuat banyak, karena kepolisian tidak bisa menetapkan hak atas tanah, dalam artian tanah ini milik siapa (kepemilikan tanah). Jika ada demonstrasi maka sudah kewajiban dari Kepolisian Sektor Pangkalan Kuras untuk mengamankan, dan jika terjadi tindak pidana maka akan diproses berdasarkan aturan yang berlaku. Selain itu kepolisian hanya menengahi dan memediasi para pihak yang terlibat konflik.

Pemerintah pusat tidak memperhatikan apakah ijin-ijin tersebut dikeluarkan di atas tanah ulayat masyarakat adat. Pemerintah hanya melihat peta saja, lalu mengeluarkan ijin. Banyak terjadi kampung-kampung yang sejak zaman Belanda sudah ada, namun diklaim berada di atas ijin yang dikeluarkan pemerintah pusat, seperti: HGU ataupun dalam kawasan Hutan Tanaman Industri (HTI), dan lain sebagainya. Akibatnya sering terjadi konflik berkepanjangan antara masyarakat dan perusahaan, tidak jarang konflik tersebut menimbulkan pengrusakan bahkan sampai menelan korban jiwa. Masyarakat memang berada pada posisi yang lemah secara hukum, karena bukti-bukti kepemilikan tanah tidak ada. Masyarakat hanya mengklaim tanah tersebut berdasarkan tombo ataupun sejarah tanah/ riwayat tanah yang tidak bisa dibuktikan secara formalitas. Sementara perusahaan selalu mengantongi ijin-ijin yang dikeluarkan oleh pemerintah pusat, yang secara hukum tentu saja sah.

Di Kabupaten Pelalawan, setiap kecamatan pasti terjadi sengketa/konflik lahan antara masyarakat adat dengan perusahaan terkait dengan tanah ulayat milik masyarakat adat yang berada di atas kawasan konsesi/HGU atau ijin lainnya yang dikeluarkan oleh pemerintah. Namun, ada 
beberapa kecamatan yang sering terjadi konflik terkait tanah ulayat ini, seperti:

1. Kecamatan Bandar Petalangan: konflik dengan perusahaan Perkebunan Kelapa Sawit, antara masyarakat Penghulu Setio Dirajo dengan PT. Serikat Putra. Tanah yang ulayat yang diperselisihkan sekitar $\pm 6000 \mathrm{Ha}$. Selain itu banyak juga konflik diwilayah Kebatinan selain Penghulu Setio Dirajo dengan Perusahaan.

2. Kecamatan Langgam: sering terjadi di Segati dan Kelurahan Langgam dengan RAPP, PT. NWR, PT. Lizwardi.

3. Kecamatan Bunut: terjadi di Desa Balam Merah.

4. Kecamatan Ukui: terjadi di desa Lubuk Kembang Bunga, Bagan Limau, Ukui 2 (dua) dengan PT. Arara Abagi, RAPP dan Limbah Lizwardi.

5. Kecamatan Pangkalan Kuras: terjadi di Desa Kusuma, Bratasena, Dundangan, Palas, Terantang Manuk dengan RAPP, Arara Abadi, PT. Safari.

6. Kecamatan Kerumutan: terjadi di Desa Tampui, Mak Teduh, Pangkalan Panduk, Tanjung Air Hitam, Lipei Bulan dengan PT. Mekar Sari dan Arara Abadi.

7. Kecamatan Pangkalan Lesung: terjadi antara Keluarahan Pangkalan Lesung dengan PT. Musim Mas dan Sari Lembah Subur.

Dari sekian banyak konflik tanah yang terjadi, tidak ada yang terselesaikan, hanya di Kecamatan Bandar Petalangan yang menempuh jalur hukum dan sampai diputus di Pengadilan Negeri Pelalawan. Namun, hasil putusannya pun masyarakat adat juga kalah. Padahal bukti-bukti sudah cukup kuat, baik berupa tombo maupun pernyataan yang dikeluarkan oleh pemerintah Belanda zaman itu. Bahkan peta tanah ulayatnya pun ada, yang dikeluarkan pemerintah Belanda zaman itu. Dalam penyelesaian konflik tersebut, pihak ketiga/ mediator sangat diperlukan, dan dalam hal ini Lembaga Adat adalah badan hukum yang pantas untuk ikut menyelesaikannya. Lembaga Adat Petalangan adalah organisasi yang menghimpun para batin dan penghulu atau setingkat batin dalam rangka menegakkan nilai-nilai adat istiadat, tuah dan marwah yang memayungi masyarakat adat dalam kawasan Hukum adat petalangan yaitu daerah Kabupaten Pelalawan.
Lembaga Adat Petalangan merupakan wadah, tempat berhimpun dan bernaung bagi seluruh masyarakat adat Petalangan. Lembaga ini diurus dan dijalankan oleh pengurus yang telah ditunjuk dan dibesarkan oleh masyarakat adat atau anak kemenakan yang menunjuknya sebagai pucuk pimpinan, ibarat pepatah orang bijak "besar batang tempat menyandar rimbun daun tempat berteduh kuat akar tempat berpegang". Pengaduan kepada Lembaga Adat Petalangan mengenai sengketa tanah ulayat antara masyarakat dengan perusahaan akibat ijin yang dikeluarkan oleh pemerintah serta penyebab timbulnya konflik di tengah-tengah masyarakat sangat banyak. Di Kabupaten Pelalawan ini pun konflik mengenai tanah-tanah masyarakat ini di setiap kecamatan pasti ada, pemerintah mengeluarkan ijin kepada perusahaan perkebunan kelapa sawit atau kepada perusahaan pengolahan kayu, seperti: RAPP dan PT. Arara Abadi tanpa memperhatikan kearifan lokal masyarakat sekitar. Akhirnya rumah-rumah penduduk, termasuk kebun-kebun penduduk termasuk ke dalam wilayah operasional perusahaan. Akibatnya lahan bertani tidak ada, masyarakat tidak bisa membuat surat-surat tanah, sehingga masyarakat sulit meminjam uang ke bank dikarenakan surat-surat tanahnya tidak bisa dibuat. Hal inilah yang menjadi awal mulanya pemicu konflik.

Pada zaman dahulunya lahan-lahan nenek moyang mereka ada yang tidak diganti rugi oleh perusahaan tersebut. Secara umum, hal-hal tersebut adalah pemicu konflik yang terjadi antara masyarakat adat dengan perusahaan. Ditambah lagi keberadaan perusahaan tidak memberikan kontribusi yang jelas bagi masyarakat tempatan, ini juga dapat menjadi faktor tambahan sebagai pemicu konflik. Jika sudah seperti ini maka penyelesaiannyapun masyarakat juga selalu mengurut dada. Letak kesulitan dalam penyelesaian sengketa tanah adat dengan perusahaan ini terjadi karena masyarakat adat menafsirkan tanah ulayat itu menurut versi adat pula, sedangkan pemerintah mengeluarkan ijin tanpa melihat kearifan lokal yang muncul di tengah-tengah masyarakat. Jika ini dihadapkan ke ranah hukum maka tentu posisi masyarakat adat sangat lemah, masyarakat adat tidak mempunyai bukti-bukti surat seperti yang dimiliki perusahaan. Masyarakat hanya didasarkan pada tombo, dan nilai-nilai yang tumbuh sejak nenek moyang mereka dahulu. 


\section{Perlindungan Hukum Terhadap Hak-}

\section{Hak Masyarakat Adat di Kabupaten}

\section{Pelalawan Terkait Dengan Penerbitan Ijin}

\section{Lahan}

Sampai sekarang di Kabupaten Pelalawan belum ada Perda yang melindungi hak-hak masyarakat adat. Peraturan turunan mengenai masyarakat adat inipun di negara kita juga tidak ada. Sehingga, terkesan negara hanya mengakui setengahsetengah mengenai masyarakat adat ini. Pemerintah dan perusahaan dalam menanggapi masalah sengketa tanah ulayat ini selalu beralasan bahwa harus mengikuti prosedur dan aturan saja, karena memang mereka diuntungkan dalam posisi tersebut. Perusahaan memiliki bukti-bukti yang kuat karena dapat ijin dari pemerintah, tetapi masyarakat adat memiliki keyakinan yang kuat juga yaitu jauh sebelum negara ini merdeka.

Kronologis masalah sengketa tanah ini bermula pada awal berdirinya PT. Serikat Putra. PT. Serikat Putra mendapatkan izin Hak Guna Usaha (HGU) seluas \pm 12.474 ha. ljin tersebut berada di atas tanah ulayat masyarakat adat di sini. Sampai sekarang yang baru diganti rugi sekitar 5.330 ha, dan yang belum di ganti rugi seluas 6.700 ha. Ini yang menjadi permasalahan bagi kami masyarakat adat Penghulu Setio Dirajo.

Jika dilihat bukti-bukti yang telah dilampirkan perusahaan mengenai ganti rugi tersebut, yang diganti rugi itu hanya tanaman hidup saja, bukan tanahnya, sehingga hal inilah yang dituntut oleh masyarakat adat. Menurut Bapak Rahman GR, masyarakat disini pada zaman itu, hanya dibodohbodohi saja oleh pihak perusahaan. Tanaman seperti karet, pisang, ubi dan lain-lain hanya diganti sekitar Rp. 15.000,sampai Rp. 30.000,- oleh pihak perusahaan kepada masyarakat. Ninik mamak atau pengurus adat pada waktu itu sering ditipu secara administrasi, karena ninik mamak/ pengurus adat tidak tahu apa-apa. Mereka mau saja disuruh untuk dimintai tanda tangan, sementara mereka tidak tahu apa isi surat yang mereka tanda tangan. Sekarang inilah yang menjadi permasalahan bagi anak kemenakan yang ditinggalkan. Mereka hanya hidup bercocok tanam, sementara lahan sekarang tidak ada.

Pemerintah pusat terkesan sengaja dalam memberikan kebijakan. Salah satu contohnya adalah ijin HGU yang diberikan kepada PT. Serikat Putra. HGU yang diberikan pemerintah kepada PT. Serikat Putra adalah HGU di wilayah tempat tinggal masyarakat di 11 desa di Kecamatan Bandar Petalangan. Jadi, dapur rumah yang ditempati oleh warga termasuk wilayah HGU perusahaan, sementara nenek moyang mereka sebelum Indonesia merdeka sudah tinggal di daerah tersebut.

Masyarakat adat sudah menggugat masalah tersebut ke Pengadilan Negeri Pelalawan, namun dalam putusannya masyarakat juga kalah. Alasan Pengadilan karena objek gugatan kabur, sementara masyarakat bisa menunjukkan objek gugatan dengan dilengkapi peta-peta yang ada dan bukti-bukti tombo serta saksi hidup yang mengetahui permasalahan ini. Pemerintah hanya sebatas mengakui hakhak adat, tetapi faktanya tidak ada pengakuan terhadap hakhak masyarakat adat. Jika berbicara tentang bukti tentu dengan ijin-ijin yang dimiliki oleh perusahaan lebih kuat, karena ijin tersebut dikeluarkan oleh pemerintah. Menurut Bapak Rahman GR (wawancara, 2015), dalam posisi ini yang dominan salah itu jelaslah pemerintah, karena pemerintah hanya berpihak kepada pengusaha dengan mengabaikan hakhak masyarakat kecil.

Kendala yang terjadi dalam menyelesaikan permasalahan tersebut di atas bagi masyarakat adat adalah Pertama, masyarakat adat lemah dari segi data dan alat bukti. Masyarakat adat hanya megantongi bukti peta lama, tombo dan tanaman dahulu, namun hal itupun sekarang sudah musnah. Sedangkan perusahaan mengantongi ijin yang dikeluarkan pemerintah. Kedua, untuk mengurus ini masyarakat adat tidak memiliki biaya, karena untuk mengambil adat yang diperlukan butuh biaya kesana-sini. Ketiga, sistem peradilan yang tidak jelas juga menjadi kendala. Pengadilan lebih berpihak kepada pemilik modal besar, sementara masyarakat kecil tidak memiliki dana. Keempat, Sumber Daya Manusia (SDM) masyarakat adat juga minim, masyarakat banyak yang tidak sekolah. Akibatnya untuk berurusan kesana-sini tidak bisa. Selain itu masyarakat adat juga memiliki mental yang lemah, sehingga untuk memperjuangkan ini tidak bisa secara menyeluruh. Kelima, banyak oknum-oknum yang selalu membacking perusahaan. Oknum tersebut rela mati demi membela perusahaan, 
sehingga banyak yang menyurutkan semangat masyarakat adat untuk memperjuangkan haknya.

Provinsi Riau menjadi primadona untuk investasi perkebunan, dengan alasan karena perusahaan beranggapan bahwa tanah ulayat di Riau ini tidak ada. Selain itu Riau juga menjadi wilayah yang aman untuk berinvestasi. Waktu itu pemerintah mendukung program-program dalam menjalankan investasi ini, sehingga investor-investor sangat tertarik untuk menanamkan modal ke wilayah Riau dan banyak perusahaan perkebunan, pertambangan dan lainlain berinvestasi di wilayah Riau.

Eksistensi tanah ulayat di wilayah hukum Kecamatan Bunut ternyata memang ada, karena selama ini konflik mengenai tanah ulayat khususnya di Kecamatan Bunut selalu ada. Jika dikalkulasikan konflik yang terjadi antara masyarakat dengan perusahaan menyangkut tanah ulayat/tanah adat selama satu tahun tidak kurang dari 5 kasus, dan konflik tanah ulayat/adat ini selalu meningkat setiap tahunnya. Kepolisian Sektor Bunut juga diikutsertakan dalam proses mediasi yang terjadi, tetapi jika proses mediasi tidak berhasil maka Kepolisian Sektor Bunut mempersilahkan masyarakat untuk menempuh jalur hukum. Kasus yang biasa terjadi sifatnya adalah perdata, namun jika ada tindak pidana maka itu baru akan menjadi kewenangan Kepolisian Sektor Bunut. Konflik antara masyarakat adat dengan perusahaan terkait masalah tanah ulayat memang selalu ada, perusahaan yang ada di Kabupaten Pelalawan selalu membawa masalah tersendiri, termasuk masalah lingkungan, tanah ulayat dan lain sebagainya.

Dari keadaan dan rumusan tentang masyarakat adat dan masyarakat hukum adat yang dikemukakan para pakar serta karakteristik dalam mengelola sumberdaya alam, tampaknya ada bagian-bagian telah diatur dan juga ada bagian yang belum diatur dalam peraturan perundang-undangan, dan bahkan ada peraturan yang saling tumpang tindih. Bagian yang belum diatur dapat dibuat aturan baru untuk melengkapinya, sedangkan pada bagian yang sudah diatur dapat diikuti dengan cara mengkritisinya, sedangkan bagian yang tumpang tindih pengaturannya perlu ditelaah mana yang lebih tepat. Terdapat beberapa prinsip-prinsip yang merupakan landasan bagi kebijakan tentang hak-hak masyarakat hukum adat antara Tanah Negara (Public Land),
Tanah Milik (Private Land), dan Hutan Negara (Public Forest), Hutan Milik (Private Forest) (Martua Sirait, dkk, hal 24). Pembicaraan tentang tanah serta hutan adalah berbicara tentang dua hal yang berbeda. Pengaturan hak atas hutan tidak akan berbicara tentang hak-hak kepemilikan (landrights), tetapi berbicara tentang hak-hak untuk menggunakan hutan termasuk dalam lingkup hak penggunaannya (userights). Dalam menyelesaikan masalah-masalah sumber daya hutan, perlu adanya kejelasan penetapan hak untuk menggunakan hutan, dan dilakukan atas dasar status penguasaan hutan, maupun berdasarkan atas fungsi lindung, konservasi, produksi maupun fungsi khusus di bidang sosial budaya maupun pendidikan dan penelitian. Dalam Undangundang Kehutanan No. 41 Tahun 1999, Kementerian Kehutanan diberikan mandat untuk menetapkan mana yang merupakan kawasan hutan dan mana yang bukan, serta juga menetapkan fungsi hutannya. Seharusnya Kementerian Kehutanan hanya menetapkan fungsi bukan statusnya, untuk mencegah conflict of interest.

Upaya menjembatani kepentingan rakyat atas tanahnya dan pemenuhan kebutuhan tanah untuk kegiatan telah dilakukan pemerintah dengan mengeluarkan Peraturan Presiden No.36 Tahun 2005 tentang Pengadaan Tanah bagi pelaksaan Pembangunan untuk Kepentingan Umum sebagai pengganti Keppres No.55 Tahun 1993. Pada awalnya Peraturan Presiden No.36 Tahun 2005 menuai kontroversi yang bersumber pada defenisi kepentingan umum yang terlalu luas dan jaminan kompensasi bagi masyarakat yang tanahnya diambil alih untuk kegiatan pembangunan demi kepentingan umum. Namun dengan dikeluarkannya Perpres No. 65 Tahun 2006 tentang Perubahan Perpres No. 36 Tahun 2005, defenisi kepentingan umum relatif lebih tegas dan berkepastian hukum, yaitu dengan berkurangnya jenis kepentingan umum dari 21 (dua puluh satu) menjadi 7 (tujuh) jenis serta penegasan pembatasan pengadaan tanah untuk kepentingan umum terbatas pada kepentingan umum yang dilaksanakan oleh Pemerintah atau Pemerintah Daerah yang selanjutnya dimiliki atau akan dimilki oleh Pemerintah atau Pemerintah Daerah. Hal lain yang perlu mendapat perhatian yaitu mengenai "ganti kerugin yang layak menurut cara yang diatur undang-undang", pemerintah sebagai pihak yang mengambil kebijakan dengan berlandaskan 


\section{MEDIA
HUKUM}

kepentingan umum, kadangkala mengabaikan hak-hak rakyat pemegang hak atas tanah tersebut. Penghormatan terhadap hak-hak atas tanah tentunya juga kepada pemegang haknya. Oleh karena itu mengenai pelepasan dan pembebasan tanah yang dikuasai oleh masyarakat adat atau tanah ulayat juga harus dilakukan sesuai dengan prosedur yang benar dan penentuan ganti kerugian yang layak.

\section{SIMPULAN DAN SARAN}

\section{Simpulan}

Kesimpulan yang diperoleh dari penelitian ini adalah:

1. Faktor-faktor penyebab tumpang tindih penggunaan lahan di Kabupaten Pelalawan adalah:

a. Belum adanya regulasi yang jelas mengenai tanah adat, sehingga hal ini merugikan para pihak yang bersengketa.

b. Perusahaan tidak memberikan ganti rugi yang layak terhadap tanah milik masyarakat adat sehingga timbul konflik.

c. Adanya protes dari anak kemenakan yang tidak mengetahui bahwa tanah adat mereka sudah dilepaskan dengan pemberian ganti rugi.

d. Pemerintah dalam mengeluarkan ijin pengelolaan lahan kepada perusahaan terkadang tidak melakukan pengecekan terlebih dahulu apakah di dalam lahan tersebut terdapat hak masyarakat adat atau tidak.

e. Ninik mamak banyak yang tidak mengurusi kepemilikan tanah adat sehingga keberadaannya pun sekarang sulit terdeteksi, dan akibatnya negara memberikan ijin pengelolaan lahan kepada perusahaan yang ternyata di lahan tersebut masih ada hak masyarakat adat.

f. Kurangnya bukti-bukti kepemilikan tanah ulayat masyarakat adat jika berperkara di pengadilan.

2. Perlindungan hukum terhadap hak-hak masyarakat adat di Kabupaten Pelalawan adalah dengan cara mengikutsertakan Kepolisian Sektor Bunut dalam proses mediasi yang terjadi, tetapi jika proses mediasi tidak berhasil maka Kepolisian Sektor Bunut mempersilahkan masyarakat untuk menempuh jalur hukum. Kasus yang biasa terjadi sifatnya adalah perdata, namun jika ada pidananya maka itu baru akan menjadi kewenangan
Kepolisian Sektor Bunut. Konflik antara masyarakat adat dengan perusahaan terkait masalah tanah ulayat memang selalu ada, perusahaan yang ada di Kabupaten Pelalawan selalu membawa masalah tersendiri, termasuk masalah lingkungan, tanah ulayat dan lain sebagainya. Tetapi dalam pelaksanaannya negara belum sepenuhnya memberikan perlindungan hukum terhadap hak-hak masyarakat adat, karena dalam kasus sengketa dan konflik tanah adat/ulayat, masyarakat adat masih berada dalam posisi yang lemah terkait dengan kebijakan yang dikeluarkan oleh negara.

\section{Saran}

Saran yang diperoleh dari penelitian ini adalah:

1. Pemerintah Indonesia harus segera melakukan inventarisir menyeluruh terhadap keberadaan tanah adat/ ulayat di Indonesia, khususnya Pemda Kabupaten Pelalawan untuk menginvntarisasi tanah adat/ ulayat di Kabupaten Pelalawan.

2. Perlu adanya Perda di Kabupaten Pelalawan yang mengatur perlindungan hukum terhadap hak-hak masyarakat adat, sehingga sengketa dan konflik tanah adat/ ulayat di Kabupaten Pelalawan dapat diminimalisir.

\section{DAFTAR PUSTAKA}

\section{Buku dan Artikel}

Adisubrata, Prent. K. dan J. Poer Wadarmita, 1960, Kamus Latin Indonesia, Semarang, Yayasan Kanisius. Akbar, M. Rizal, dkk, 2005, Tanah Ulayat dan Keberadaan Masyarakat Adat, Pekanbaru, LPNU Press Arif, Ahmad dan Agnes Rita, Sayap Patah Para Sakai, Koran Kompas, 24 April 2007.

Bakri, Muhammad, 2007, Hak Menguasai Tanah Oleh Negara, Jakarta, Citra Media

Fajar, Mukti, dan Yulianto Achmad, Dualisme Penelitian Hukum Normatif dan Empiris, Yogyakarta, Pustaka Pelajar

Harsono, Boedi, 2005, Hukum Agraria Indonesia, Sejarah Pembentukan Undang-Undang Agraria, Isi dan Pelaksanaannya, Jakarta, Djambatan

Kartasapoetra, G, et. al, 1985, Hukum Tanah Jaminan UUPA Bagi Keberhasilan Pendayagunaan Tanah, Semarang, Bina Aksara 
Otje, Salman, 2002, Rekonseptualisasi Hukum Adat Kotemporer, Bandung, PT. Alumni.

, dan Anthon F. Susanto, 2007, Teori Hukum, Mengingat, Mengumpulkan dan Membuat Kembali, Bandung, Refika Aditama,

Riyanto, Budi, 2006, Hukum Kehutanan dan Sumber Daya Alam, Bogor, Lembaga Pengkajian Hukum Kehutanan dan Lingkungan

Soekanto, Seorjono, 2003, Hukum Adat Indonesia, Jakarta, PT. Raja Grafindo Persada

Sunarno, dalam "Incorporating good Land governance In the disaster region of Yogyakarta, Jurnal Media Hukum Volume 22, No.1 Juni 2015

Strong, CF, 1952, Modern Political Constitution, Sidwick \& Jason Limited, London, 1952.

Yayasan Hutan Riau, Analisis Pemberian Izin Konsesi di Riau, Studi Kasus: Siak dan Pelalawan, Pustaka Pelajar, Yogyakarta, 2015.

Zein, Ramli dan Tunas Effendi, dkk, 2005, Hutan Ulayat dan Permasalahannya, Pekanbaru, Lembaga Kerapatan Adat Melayu Kabupaten Pelalawan

St. Paul, Minn, Black Law Dictionary, West Publishing Co, 1983.

\section{Peraturan Perundang-Undangan}

Undang-Undang Dasar 1945.

Undang-Undang Nomor 5 Tahun 1960 tentang Peraturan Dasar Pokok-Pokok Agraria. 